\title{
JAN III SOBIESKI POD WIEDNIEM W LITERACKIM ŚWIADECTWIE EPOKI (REKONESANS)
}

\author{
Piotr Borek
}

http://orcid.org/0000-0003-3031-7722

Uniwersytet Pedagogiczny im. Komisji Edukacji Narodowej w Krakowie

\section{ABSTRACT \\ SOME REMARKS ON JOHN III SOBIESKI AT VIENNA IN THE LITERARY TESTIMONY OF THE TIME}

The Vienna campaign of King John III Sobieski was widely reflected in the literature: diaries, journals, letters and chronicles. The apologies of the victory of the Polish monarch occurred in many occasional works. Most of them were panegyrical. According to the calculations of researchers (Bolesław Klimaszewski, Juliusz Nowak-Dłużewski), about a dozen or so tales were created. Most poetry on this subject is quite average in terms of artistic skill. It should be remembered, however, that the preserved literary texts (written in Polish and Latin) were meant to glorify the success of the Polish army at Vienna and especially John III Sobieski. His image is heroic, and sometimes sacred. Among the dozen or so poets, Wespazjan Kochowski deserves attention as the one who devoted several works to the subject of victory at Vienna. Apart from favourable evaluations, there were also a few voices criticizing Sobieski’s foreign policy (for example, Wacław Potocki).

Keywords: John III Sobieski, Vienna 1683, panegyric poetry, literature and history, axiology in occasional literature.

Słowa kluczowe: Jan III Sobieski, Wiedeń 1683, poezja panegiryczna, literatura a historia, aksjologia w literaturze okolicznościowej.

Kampania wiedeńska Jana III Sobieskiego znalazła duży oddźwięk w prozie diariuszowo-pamiętnikarskiej, kronikarskiej oraz epistolografii, ale nie tylko. Uświetnieniu wiktorii polskiego monarchy poświęcono dziesiątki utworów okolicznościowych, w większości panegiryków. Wedle wyliczeń Bolesława Klimaszewskiego „w gronie 26 pisarzy sławiących to zwycięstwo znaleźli się zarówno ci, których powiązania literackie z osobą Jana III datowały się znacznie wcześniej, jak i ich następcy, dla których dzieła poświęcone wyprawie wiedeńskiej stanowiły dopiero początek 
zainteresowań poczynaniami króla - wojownika"1. Dalej zaś badacz stwierdził, iż „w ostatnich miesiącach 1683 i w całym 1684 powstało ponad 50 pozycji literackich, niejednakowej wprawdzie wartości i objętości, lecz poświęconych jednej osobie i jednemu wydarzeniu" 2 . W tym miejscu pomijam obecność postaci Jana III w literaturze i piśmiennictwie zachodnioeuropejskim, w których również dostrzegano wagę zwycięstwa wiedeńskiego oraz pozytywnie pisano o panowaniu monarchy - w sumie do schyłku XVIII stulecia powstało na Zachodzie kilkaset dziełek, w których pojawiał się Sobieski (najwięcej na Półwyspie Apenińskim - ponad dwieście)³.

Zdaniem Juliusza Nowaka-Dłużewskiego całość materiału literackiego okresu odsieczy wiedeńskiej „układa się w dwie grupy gatunkowe: najwięcej jest utworów lirycznych, i to określonego charakteru, mniej epickich relacji wydarzenia"4. Jak zauważył badacz, w tym kontekście interesujący okazuje się łaciński wiersz zatytułowany Vox clamantis in Deserto - dziełko poprzedzające kampanię wiedeńską, utrzymane w tonacji alegorycznej rozmowy między upersonifikowanym Głosem (Vox) a Polską, którą pragnie on skłonić do wystąpienia przeciw universum hostem, czyli Turcji. Gdy strapiona Ojczyzna rozważa, jakie kroki ma podjąć, Vox odpowiada, że promotorem sukcesu będzie Bóg, a ponadto ubique habetis Joannem, magnum ducem totius christianitatis, cum quo manus fuerit Domini semper ${ }^{5}$ - Jan III, wielki wódz chrześcijaństwa, wspierany jest zawsze ręką Boga. Jak można mniemać, co podkreśla Nowak-Dłużewski, tekst stanowił rodzaj lirycznej propagandy, promującej ukonstytuowanie koalicji antytureckiej - Ligi Świętej tworzonej przez papieża z pomocą Austrii i Wenecji ${ }^{6}$. Warto dodać za badaczem, że w dziełku pobrzmiewa nuta krytycyzmu względem Brandenburgii i Francji.

Wśród wielu drugorzędnych tekstów o tematyce wiedeńskiej, na które zwrócił uwagę Nowak-Dłużewski, warto przyjrzeć się kilku. Co istotne, kryterium waloryzacji tych zabytków literackich stanowi nie tyle strona literacka, ile rys dokumentarny, weryzm. O Wiedniu pisał anonim w dziele Opisanie potrzeby wiedeńskiej $A D$ 1683, w którym zarysował rozmiar strat wojsk sprzymierzonych, a także ks. Herman Drobiszewski w Opisaniu roku 1683 i oblężenia wiedeńskiego ze Selimem sułtanem czwartym przez Wezyra - jego literacka relacja ma strukturę diariuszową, rekonstruuje dzień po dniu fazy oblężenia ${ }^{7}$. Wypada również wspomnieć nietuzinkowego poetę polskiego baroku, Jana Gawińskiego, który w roku 1680 napisał poemat zagrzewający do walki z Turcją Clypeus Christianitatis to jest Tarcz Chrześcijaństwa. W partii inicjalnej liryk ten kierował do monarchy pobudkowy apel:

1 B. Klimaszewski, Jan III Sobieski w literaturze polskiej i zachodnioeuropejskiej XVII i XVIII wieku (Zeszyty Naukowe Uniwersytetu Jagiellońskiego. Prace Historycznoliterackie, z. 48), WarszawaKraków 1981, s. 26.

2 Ibidem, s. 26-27.

3 Takiego zestawienia dokonał cytowany Bolesław Klimaszewski.

4 J. Nowak-Dłużewski, Okolicznościowa poezja polityczna w Polsce. Dwaj królowie rodacy, oprac. S. Nieznanowski, Warszawa 1980, s. 119.

5 Cyt. za: J. Nowak-Dłużewski, op. cit., s. 122.

Ibidem.

7 Ibidem, s. 125-127. 
My wierzem,

Że Cię Bóg przeciw niemu nam Cię dał puklerzem,

Jemu zgubą, nam zdrowiem. Ty, nasz Scypijonie,

Wielki Fabi, obroną swej masz być Koronie.

$[\ldots]$

Ty dziedzictwo Lechowe z daleka i z bliża

Masz bronić mocą Twego i cnotą paiża,

Z którego wyrok Boży, gdy rzecz swą zaczyna,

Mnie pod nogi twe upaść z muzą napomina ${ }^{8}$.

Panegiryk wydał także Stanisław Chrościński - Trąbe wiekopomnej sławy i pamięci Najjaśniejszego i niezwyciężonego Jana III... wiedeńska i parkańska oraz z Turczynem Wiktoryja opiewajace (Warszawa 1684). Tekst obejmuje sto kilkanaście oktaw prezentujących alegoryczne zmagania między orłami (symbolizującymi chrześcijan) a ptactwem podlejszego gatunku (wyznawcami islamu). Pod Wiedniem był również dworzanin Jana III Jakub Kazimierz Rubinkowski, który pozostawił po sobie szereg panegiryków. Wśród nich najbardziej apologetyczny okazuje się monumentalny utwór Janina zwycięskich tryumfów dziełami i heroicznym męstwem Jana III króla polskiego na marsowym polu najjaśniejszy... (Poznań 1739).

Warte odnotowania jest także dziełko profesora matematyki Akademii Zamoyskiej Jana Stanisława Niewieskiego zatytułowane Opisanie wierszem klęski Turków pod Wiedniem (druk w kalendarzu za rok 1685). Autor stosuje konceptystyczne zestawienie Jana III z Aleksandrem Wielkim: „Sameś wszędy nadjeżdżał, dodając ochoty, / Doszedłeś Aleksandra Wielkiego z tej cnoty, / Czujno, mądrze, odważnie traktując te rzeczy, / Świat ci to musiał przyznać, żeś monarcha grzeczny"9.

Z utworów łacińskich o kampanii wiedeńskiej należy za Juliuszem Nowakiem-Dłużewskim wymienić Jana Wojciecha Janickiego Io trumphale..., Wojciecha Bartochowskiego Fulmen orientis Joannes III..., Jakuba Boczyłowica Sarmatia laureata i zwłaszcza drukowaną w Wenecji i niezwykle popularną na Zachodzie Sobiesciadę Jędrzeja Wincentego Ustrzyckiego, monumentalną (ponad 4 tysiące heksametrów) pochwalną biografię Sobieskiego (od narodzin po Wiedeń) ${ }^{10}$. Nieco słabszy literacko był poemat Viennis autorstwa Jana Damascena Kalińskiego ${ }^{11}$. Na zakończenie tego wyliczenia trzeba też wspomnieć o barokowej pisarce Annie Zbąskiej ze Stanisławskich, autorce wierszowanego pamiętnika Transakcyja albo opisanie całego życia jednej sieroty. W trenie numer 72 Zbąska opisała odsiecz wiedeńską, podczas której umarł jej trzeci mąż - Zbąski (,Jużby dalej nie wytrzymał / Wiedeń, co się dotąd trzymał; / Leć już odetchnęli sobie, / Co być spodziewali w grobie. / Wiwat już wszyscy wołają, / Salwatorem nazywają / Króla, co deliberował, / Jakby ich życiem darowa1") $)^{12}$.

8 J. Gawiński, Clipaeus Christianitatis to jest Tarcz Chrześcijaństwa, oprac. D. Chemperek, W. Walecki, Kraków 2003, s. 30.

9 Cyt. za: J. Śliziński, Jan III Sobieski w literaturze narodów Europy, Warszawa 1979, s. 67.

10 Por. J. Nowak-Dłużewski, op. cit., s. 130-134.

11 Ibidem, s. 134.

12 Cyt. za: J. Śliziński, op. cit., s. 73. 
Niewątpliwie najwięcej dla upamiętnienia sukcesu Jana III Sobieskiego pod Wiedniem uczynił Wespazjan Kochowski, uczestnik wyprawy i historiograf królewski. Jego zamiarem było stworzenie epopei w oktawach - najkunsztowniejszej odmianie stroficznej - czczącej sukces polskiego oręża, a zwłaszcza Jana III. Mowa tu o utworze Dzieto Boskie albo Pieśni Wiednia wybawionego i inszych transakcyjej wojny tureckiej... (Kraków 1684). Dziełko w zakresie kreacji panegirycznej wzorowane było na Jerozolimie wyzwolonej Torquata Tassa. Kochowski inspirował się barokową epopeją, kreując dwa plany rozpatrywania historii: doczesny (ziemski) oraz metafizyczny (przeciwstawienie się siłom szatańskim utożsamianym z armią turecką). Ostatecznie polskiemu poecie starczyło sił na pierwszą pieśń, w której wysławiał monarchę. O kłopotach w tworzeniu rymów pisał w zwrocie Do czytelnika, twierdził, że zarzucił już poezję na rzecz prozy historycznej (,Nie mam w zwyczaju na świat podawać jakichkolwiek lukubracyj moich kwapionego konceptu partum; bo mimo to, żem conscius nieudolności własnej, dawnom już abdykował poesim polską, moję niegdy w młodym wieku zabawę ad interim annalibus patrii poświęciwszy pióro"13). Mowa tu zatem o braku wiary w swój talent wierszopisarski, który poeta chciał przełożyć na opisanie „na wszytek świat sławnej Jego Królewskiej Mości Pana naszego miłościwego wiktoryi”'14. Autor Dzieła Boskiego... podejmuje się zadania opisu wydarzeń w mowie wiązanej, aby wypełnić lukę spowodowaną brakiem pochwały zwycięstwa w języku narodowym. Dalej w zwrocie do czytelnika następuje zestawienie Sobieskiego z Gotfrydem de Bouillon (aluzja do Tassa). Paralela z wyprawami krzyżowymi stanowi jeden ze składników heroizacji czynów Sobieskiego i jego armii. Monumentalizacja sukcesu dokonuje się zarazem przez wyzyskanie wzorca epiki wysokiej, to jest eposu: nie tyle jednak jego odmiany homeryckiej i wergiliańskiej, ile lukanowej (mowa o dziele Lukana Pharsalia, opisującym konflikt pomiędzy Cezarem a Pompejuszem z lat 49-47 p.n.e. ${ }^{15}$.

Różnica między odmianami eposu zasadzała się przede wszystkim na tym, że Lukan opiewał dzieje sobie współczesne, a Homer i Wergiliusz sięgali do zamierzchłej przeszłości, wprowadzając ogromny dystans czasowy, Lukan ograniczał także element cudowności, obecny w eposach homeryckich. Co istotne, nowożytna odmiana eposu respektowała szereg składników gatunku: sceny bitewne, szeregi pojedynków, oracje bohaterów, rozległe opisy wojsk i pojedynczych bohaterów.

Dla wykreowania pozytywnego wizerunku polskiej armii i jej wodza Kochowski miał wzorce bliższe czasowo, a mianowicie dzieła epickie Samuela Twardowskiego - przede wszystkim epos biograficzny Władystaw IV oraz Wojnę domowa, ponadto Wacława Potockiego Transakcyję wojny chocimskiej. Warto zwrócić uwagę na paralelę formuł tytułowych przekładu Tassowskiego dzieła pióra Piotra Kochanowskiego Gofred abo Jeruzalem wyzwolona i Wespazjana Kochowskiego Dzieto Boskie albo

13 W. Kochowski, Dzieło Boskie albo Pieśni Wiednia wybawionego i inszych transakcyjej wojny tureckiej [w:] idem, Utwory poetyckie. Wybór, oprac. M. Eustachiewicz, Biblioteka Narodowa. Seria I, nr 92, Wrocław-Warszawa-Kraków 1991, s. 365.

14 Ibidem.

15 Zwraca na to uwagę Maria Eustachiewicz we Wstępie do edycji: W. Kochowski, Utwory poetyckie..., s. LIV-LV. 
Pieśni Wiednia wybawionego. Zarówno „wybawienie” Wiednia, jak i „wyzwolenie” Jerozolimy dokonują się za sprawą rycerstwa chrześcijańskiego, dowodzonego przez namaszczonych przez Boga wodzów.

Poeta inicjuje narrację opisem przygotowań do wojny, którym sprzyjają życzliwe niebiosa ${ }^{16}$. Z kolei siły piekielne wspierają Turków, dążących do unicestwienia chrześcijaństwa. Przeniesienie sensu konfliktu na plan metafizyczny (walka dobra ze złem) służyło nobilitacji wydarzeń doczesnych. W tej perspektywie Sobieski stawał się mężem opatrznościowym, uwalniającym Europę od zalewu potęgi otomańskiej. Jak można mniemać, zamierzeniem Kochowskiego było przedstawienie dłuższego okresu wojen z Turcją - pieśń pierwsza dotyczyła kampanii wiedeńskiej (poselstwo Walsteina, wymarsz wojska, bitwa pod Wiedniem i spotkanie z cesarzem Leopoldem) - tytuł całości zawiera informację, że w dziele będzie mowa też o „inszych transakcyjach" wojennych. Ostatecznie, jak wspomniano, Kochowski nie rozwinął poematu i poprzestał na pieśni pierwszej, która w tej postaci okazuje się epinikionem - pieśnią pochwalną zwycięstwa i Sobieskiego.

Laudacja Jana III modelowana jest nie tylko przez eksponowanie roli wodza, czyli opis czynów i decyzji monarchy. Ważną funkcję parenetyczną pełni przedmowa, w której poeta zwraca się do syna króla - Aleksandra, ukazując cnoty jego ojca:

Najaśniejszemu Panu a Panu Aleksandrowi z łaski Bożej Królewiczowi Polskiemu autor zdrowia dobrego życzy

I

Do kogóż słuszniej obrócić się miały

Wybawionego Wiednia moje rymy,

Jeno do ciebie, wielkiego, wspaniały

Rodzica synu, następco estymy,

Cny królewicze. Ty, choć niedojrzały

Wiekiem, już gromisz tureckie olbrzymy,

Samym imieniem straszny. Cóż gdy w pole

Ruszysz - o zadrży Konstantynopole!

II

Poznać i w dziatkach, z których będą męże,

Wynika na wierzch czerstwość przyrodzona;

Czaczkiem go nie tul, ale daj oręże,

Zaraz Achilla uwodzi Bellona.

Jeszcze w kolebce Annibal gniótł węże,

Choć młodo, poznać z humoru Katona,

Aleksandrowi należyta chwała,

Że przed inszymi dosiadł Bucefała.

III

Lecz na cóż dawne wzbudzać kawalery,

Co późnym wiekom pobudką do cnoty?

Dość, żeś ojcowskiej żywy abrys cery

16 Ibidem, s. LVII. 
Wstępując w jego chwalebne przymioty.

Ty, da Bóg, z nim wraz tureckiej Chimery

Strącisz poroże, a wróciwszy złoty

Wiek chrześcijaństwu, ku jego pociesze,

$\mathrm{Z}$ znakami pójdziesz ku arabskiej Mesze.

\section{IV}

Nadzieja w Bogu, iże w jego ślady

Wstąpisz i z chuci, i prawem dziedzicznym,

Jego cię ze snu obudzą przykłady,

Które przeczytasz w wierszu heroicznym,

Abyś tym wzorem turskie Enkelady

$\mathrm{Na}$ upad konał bojem ustawicznym,

A tak Ottoman tę będzie miał chlubę,

$\mathrm{Z}$ rąk Aleksandra, iże odniósł zgubę.

Waszej Królewskiej Mości Pana Mego Miłościwego

uniżony sługa Wespazyjan Kochowski z Kochowa, dworzanin J. K. M. ${ }^{17}$

Uogólnienie wiedeńskich wypadków następuje przez wprowadzenie dystansu czasowego (pamiętajmy, że dzieło wydano zaledwie kilka miesięcy po wiktorii), dystansu zatem sztucznie budowanego, by wzorzec rycerza chrześcijańskiego, Sobieskiego, pogromcy Turka, na tyle już ucukrował i okrzepł, by pełnić funkcje wychowawcze. Perswazyjny charakter zwrotu do Aleksandra nie budzi wątpliwości - ma naśladować i rozwijać, a nawet pomnażać sukcesy ojca, by unicestwić Portę.

Samą narrację Kochowski rozpoczął apostrofą do muzy Klio mającej upamiętniać czyny monarchy. W dalszych oktawach pogańską muzę zastępuje Matka Boska - wszak poeta opisuje wojnę chrześcijańską, a głównym herosem jest miles christianus Jan $\mathrm{III}^{18}$ :

\section{I}

Możnego Króla wiekopomne dzieła

Ojczystym rymem wspomni, Klijo chętna,

Które lub sława światu ogłosiła,

Jednak potomność niech będzie pamiętna,

Jako posoki bisurmańskiej siła

$\mathrm{Z}$ jego przywodu leje szabla skrzętna,

Kędy przeszedszy Odry i Dunaje

Piorunem wojny poganom się staje.

II

Klijo, nie ty, co w dwójwierzchym Parnasie

Pierwsza przodkujesz w dam dziewiętnych gronie,

A doświadczonych głów przy mądrej prasie

Otaczasz wieńcem wawrzynowym skronie;

Ale ty, Panno, któraś Boga w czasie

17 W. Kochowski, Dzieło Boskie..., s. 316-318.

18 Por. M. Eustachiewicz, op. cit., s. LVII. 
Zrodziwszy, siedzisz w gwiaździstej koronie,

Ty mi bądź Klijo, ty mi w tym usiłku

Dodaj słów Panno, dodaj i posiłku.

III

Idzie tu o cześć, idzie i o wiarę

Syna Twojego, nam drogie klejnoty,

Które, kiedy by Turczyn przebrał miarę

W swej nadętości, nie uszły sromoty.

Zniósłby w świątnicach bezkrewną ofiarę

I katolickich obrzędów prostoty,

A na to miejsce tyran rozdrażniony

Wprowadziłby nam brzydkie zabobony.

IV

O nie dopuścisz! aby kiedy twoje

Dziedzictwo burzył naród ten wszeteczny;

Uprosisz ducha zgody, a na boje

Serce odważne i umysł stateczny,

A uśmierzywszy wnętrzne niepokoje

Chrześcijańskimi między pany wieczny

Skojarzysz związek. Niechaj co się kłócą

$\mathrm{Z}$ sobą, te siły na Turki obrócą ${ }^{19}$.

Podkreślenie rangi polskiego monarchy dokonuje się nie tylko przez ukazanie wpisanego w jego charakter systemu wartości (cnota wiary jest bez wątpienia nadrzędna). Funkcję laudacyjną pełni także opis spotkania Jana III z cesarzem, który nazwał Sobieskiego obrońcą całego chrześcijaństwa. Odpowiedź polskiego monarchy kładzie nacisk nie tyle na męstwo, ile na Bożą opatrzność, która dokonała tego cudu. Pogłos takiego właśnie przekonania Jana III odnajdujemy w jego słynnym liście o zwycięstwie: „Bóg i Pan nasz na wieki błogosławiony dał zwycięstwo i sławę narodowi naszemu, o jakiej wieki przeszłe nigdy nie słyszały”20. Zatem tytułowe „dzieło Boskie" stanowi poniekąd kalkę ideową przekonań samego monarchy - rycerza Chrystusowego ${ }^{21}$. Kochowski wykreował scenę spotkania władców zgodnie z ideą pokoju i zgody, sankcjonującej możliwość ostatecznego pokonania „półksiężyca”:

CIV

Tu pierwszy cesarz w paludament strojny,

Słowy przywita gościa poważnymi:

Witaj, o Królu, tak chwalebnej wojny

Możny zwyciężco z Sarmatami twymi

I któryś zdrowia, i głowy dostojnej

Nie chronił dla nas i rakuskiej ziemi,

Aleć nie tylko austryjackie państwo,

Lecz zaszczyciłeś całe chrześcijaństwo.

19 W. Kochowski, Dzieto Boskie..., s. 318-320.

20 J. Sobieski, Listy do Marysieńki, oprac. L. Kukulski, Warszawa 1970, s. 522.

${ }^{21}$ Por. ibidem, s. LX. Warto dodać, że podobną wymowę ma wydane w roku 1684 łacińskie dzieło W. Kochowskiego Commentarius belli adversus Turcas ad Viennam et in Hungaria. 
CV

Po Bogu tobie, wielki kawalerze,

Ten dank należy, że wezyr złamany.

Tyś bowiem jeden miecz twój gwoli wierze

Mężny przypasał na same pogany;

Przez cię Krzyż Pański podwyższenie bierze,

Dotąd od Turka sromotnie deptany,

Których odważnych prac twoich i chęci

Wieczne w sercu mym wyryte pieczęci.

\section{CVI}

Na które słowa odpowie wspaniały

Król cesarzowi obłapiwszy mile;

Co w oczach świata niedawno się stały

Cuda, wprzód Boskiej trzeba przyznać sile,

Który zgniótł naród pyszny i zuchwały

I jako rózgą rozpędził motyle;

Potem cesarzu nigdy nie zwalczony

Twej to czułości dziełem i fortony.

\section{CVII}

Nam jeżeli część jaka się okrawa

Pracy i sławy z tak krwawego boju,

Wszytka się spólną z chrześcijaństwem stawa,

Dla beśpieczeństwa wiernych i pokoju.

Wreszcie jeżeli jeszcze co zostawa

I zdrowie, i krwie by w ostatnim znoju,

Odważemy to. Dla prawdziwej wiary

Niestraszny ogień, działa, miecze, mary ${ }^{22}$.

Kochowski dokonuje sakralizacji zwycięstwa wiedeńskiego także w swej Psalmodii polskiej (Częstochowa 1695). Co istotne, w stylizowanym na starotestamentowe psalmy zbiorze akcent przesunięty jest z monarchy (i w ogóle działalności władcy jako człowieka) na samego Boga, zwycięzcę zajadłego „bazyliszka oryjentalnego”. Pochwała Jana III uchwytna jest w Psalmie XXVII, w którym czytamy o dobrym czasie panowania nad Rzecząpospolitą: „,najjaśniejszego Jana III, który jest człowiekiem od Boga posłanym: aby nademdloną dźwigał Sarmacyją"23. Pokonanie potęgi tureckiej pod Wiedniem wspominane jest także w innych psalmach. W finalnym Psalmie XXXVI, stylizowanym na biblijny Psalm 90, dostrzec można sakralizację konfliktu Rzeczypospolitej z Portą. Jak czytamy w tytule utworu, Boską opiekę dało się zauważyć szczególnie „teraz, podczas walnej wojny tureckiej””24. Polska armia ma

22 W. Kochowski, Dzieło Boskie..., s. 362-363.

23 Idem, Trybut należyty wdzięczności wszystkiego dobrego dawcy Panu i Bogu albo Psalmodia Polska za dobrodziejstwa Boskie dziękująca... [w:] idem, Utwory poetyckie..., s. 435.

${ }^{24}$ Kochowski projektuje w Psalmodii polskiej ideę szczególnego posłannictwa Polski wśród europejskich państw chrześcijańskich. Dowodem na to ma być właśnie opieka, jaką Bóg otaczał naród sarmacki: „18. Rozkaż aniołom Twoim o koronowanej głowie: aby jej strzegli we wszytkich drogach i zawodach jej. 19. Niech ją sprawujące duchy na ręku noszą; a przezornego oka Twego opieka niechaj 
w zasadzie realizować Boski plan unicestwienia wojsk tureckich. Najpełniej tę perspektywę ujawnia Psalm XXIV, stanowiący wykładnię sensów wiktorii wiedeńskiej (rola Sobieskiego została tu pomniejszona na rzecz roli Boga):

\section{PSALM XXIV}

VENITE EXULTEMUS DOMINO PS 94

PAMIĄTKA ODSIECZY WIEDNIOWI DANEJ R. P. 1683 DNIA 13 SEPTEMBRA

1. Pódźcie, radujmy się Panu, śpiewajmy Bogu Zbawicielowi naszemu, uprzedźmy oblicze Jego z dziękczynieniem: a przez pieśni i hymny wychwalajmy niewysłowioną dobrotliwość Jego.

2. Albowiem Pan jest Bóg wielki, który czyni wszytko z nizczego: i Król możny, który z ostatniej toni zgubionych wyratować może.

3. Ten cię, zdesperowany Wiedniu, wydrze z ręki olbrzyma za garło cię trzymającego: i zrazi krwawą bestyją, paszczękę na cię rozdzierającą.

4. Który Konstantyna upewnił w znaku krzyża o zwycięstwie: ten i tobie pewne hasło daje, że w tymże znaku prędkiego dostąpisz wybawienia.

5. Podnieś oczy twoje na góry: a tam ujrzysz gęste chorągwie, z tym znamieniem w posiłek ci idące.

6. Rzuć wzrokiem, ile można, na niebotyczne, drzewami okryte skały: z których wielkim pędem wylatują mężni orłowie na wybawienie twoje.

7. Już, już Kara Musztafa, libickiego lwa szczenię, zajrzawszy krzyża, trwożyć sobą poczyna: i ono Lucyperowej pełne pychy serce zbierać każe namioty!

8. Już odjął świetną od zawoju forgę: czy że się w drogę gotuje, czy głowę ułatwiając, po którą niezadługo stambolskie emiry przyjdą.

9. Baszów i bellerbejów hucznych tchórz obleciał: co żywo w drogę, gdy już ciężkie bazary w srogim zamieszaniu nazad uchodzą.

10. Działa i kartany ich nie huczą, ale wyją: a wyrzucona minami ziemia na nichże leci, chcąc pogrześć jeszcze żyjących.

11. Więc co wskok, obleżęńcy, pódźcie i upadajcie przed tronem Najwyższego: dziękujcie Panu, który was stworzył, i wielbiejcie Go, który wam i teraz powtórnie daje zbawienie.

12. Dziś jeno głos odsiecz niosących usłyszycie, nie zatwardzajcie serc waszych bojaźnią: ale wdzięczni ratunku do nieba ręce podnoście.

13. Wypadajcie, młodsi, i kto broń w ręku uniesie, na zdjęte strachem nieprzyjacioły: a wy, starcy i z niebitną gawiedzią po blankach murów tryumfalny hymn zaczynajcie.

14. I uczyńcie okrzyk wesoły, jako po wygranej bitwie: i niech publicznej radości ogniami Stefanowa wieża rozjaśnieje.

15. Tak, jak czasu Solimanowego od Wiednia odwrotu: gdzie także ojcowie waszy doznali pomocy Pana Zastępów.

Chwała Ojcu i Synowi, i Duchowi Ś. etc. ${ }^{25}$

Nie ma wątpliwości, że zachowane teksty literackie promują sukces polskiego oręża pod Wiedniem, a zwłaszcza Jana III Sobieskiego. Jego wizerunek ulega monumentalizacji, nabiera rysów heroicznych, niekiedy wręcz nasyconych elementami sacrum. Rozmiary i znaczenie sukcesu kampanii wiedeńskiej zasługiwały wszakże

nad nią nieustannie zostaje. 20. Po schizmatyckiej żmijej, jad pod językiem mającej, niechaj chodzi: i niech podepce bazyliszka oryjentalnego. 21. Ty rzucisz pod nogi jego opiłego krwią niewinną smoka: a z libickiej jaskini lew męstwem się jego niech zatrwoży. 22. Nasyćże go długich dni, o Najwyższy: i w owocu jego pokaż nam zbawienie Twoje" (ibidem, Psalm XXXVI, s. 456).

25 Ibidem, s. 424-425. 
na takie upamiętnienie. Niezależnie bowiem od konwencji panegirycznych, jakie przyjmowali prawie wszyscy literaci opiewający to wydarzenie, było ono kluczowe dla dalszych losów Europy i zatrzymania ofensywy islamskiej na kontynencie europejskim.

$\mathrm{Na}$ koniec warto sięgnąć po ustalenia przywoływanego wcześniej J. Nowaka-Dłużewskiego, który w swej pracy wskazał kilka barokowych utworów negatywnie waloryzujących kampanię wiedeńską i postawę Sobieskiego. Jak zauważył badacz, niepochlebnie o polityce Sobieskiego wypowiadał się Wacław Potocki w Moraliach i Ogrodzie fraszek. Krytyka nie tyle może uderzała w samego monarchę, ile szerzejcałą politykę dworu. Potocki, niechętny Austriakom, nie widział politycznego sensu w przelewaniu krwi pod Wiedniem ${ }^{26}$. W epigramacie Przyjaźń pogańska krytycznie ocenił współpracę francusko-turecką oraz wskazał na radość Porty z kłótni monarchów chrześcijańskich. Z kolei we fraszce Powrót z Węgier wojsk obu drwił z pościgu za Turkami: „Rozgromiwszy w Rakuszech Polacy Połańce, / Sraczki, a Litwa z Węgier nawiozła nam france. / Którą by z tych obierać, powiedzcie doktorzy? / Ja wolę francę: sraczka i śmierdzi, i morzy”27.

\section{BIBLIOGRAFIA}

\section{Źródła}

Gawiński J., Clipaeus Christianitatis to jest Tarcz Chrześcijaństwa, oprac. D. Chemperek, W. Walecki, Kraków 2003.

Kochowski W., Commentarius belli adversus Turcas ad Viennam et in Hungaria, Cracoviae: Wojciech Gorecki, 1684.

Kochowski W., Utwory poetyckie. Wybór, oprac. M. Eustachiewicz, Biblioteka Narodowa. Seria I, nr 92, Wrocław-Warszawa-Kraków 1991.

Sobieski J., Listy do Marysieńki, oprac. L. Kukulski, Warszawa 1970.

\section{Opracowania}

Eustachiewicz M., Wstęp [w:] W. Kochowski, Utwory poetyckie. Wybór, oprac. M. Eustachiewicz, Biblioteka Narodowa. Seria I, nr 92, Wrocław-Warszawa-Kraków 1991.

Klimaszewski B., Jan III Sobieski w literaturze polskiej i zachodnioeuropejskiej XVII i XVIII wieku (Zeszyty Naukowe Uniwersytetu Jagiellońskiego. Prace Historycznoliterackie, z. 48), Warszawa-Kraków 1981.

26 Szerzej zob. J. Nowak-Dłużewski, op. cit., s. 143-147.

27 Ibidem, s. 146. 
Nowak-Dłużewski J., Okolicznościowa poezja polityczna w Polsce. Dwaj królowie roda$c y$, oprac. S. Nieznanowski, Warszawa 1980.

Śliziński J., Jan III Sobieski w literaturze narodów Europy, Warszawa 1979. 